\title{
RELATIONS OF THE WASATCH AND GREEN RIVER FORMATIONS IN NORTHWESTERN COLORADO AND SOUTHERN WYOMING, WITH NOTES ON OIL SHALE IN THE GREEN RIVER FORMATION.
}

\author{
By J. D. Sears and W. H. Bradley.
}

\section{INTRODUCTION}

\section{PURPOSE AND SCOPE OF THE REPORT.}

Since the early geologic explorations of Powell, King, and Hayden the Eocene deposits of the Rocky Mountain and Plateau provinces have been the object of much attention by stratigraphers. More widespread interest in these deposits has been stimulated by the discovery of vast quantities of oil shale in the Green River formation of Wyoming, Colorado, and Utah.

The writers have had an opportunity to see the depositional edge of the Eocene formations on the northeast flank of the Uinta Mountains and to study the significance of their character along this margin as compared with their character farther out in the basin. The purpose of this report is to describe the lithology, areal distribution, and interfingering of the Wasatch and Green River formations in northwestern Colorado and southern Wyoming and to draw conclusions as to their source of material, mode of origin, time relations, and proper nomenclature. The method and place of deposition are of special importance in considering the Green River formation, as they largely determine the relative richness of the oil shale found in that formation.

\section{EARLIER INVESTIGATIONS.}

The area discussed in this paper is part of the region explored half a century ago by Hayden, ${ }^{1}$ Powell, ${ }^{2}$ Hague and Emmons, ${ }^{3}$ and King. ${ }^{4}$

1 Hayden, F. V., U. S. Geol. Survey Terr. Third Ann. Rept., 1869.

2 Powell, J. W., Report on the geology of the eastern portion of the Uinta Mountains, U. S. Geol. and Geog. Survey Terr., 2d div., 1876.

${ }^{3}$ Hague, Arnold, and Emmons, S. F., U. S. Geol. Expl. 40th Par Rept., vol. 2, 1877.

4 King, Clarence, idem, vol. 1, 1878. $33372^{\circ}-25-7$
Hayden named the Green River and Wasatch formations, and the latter name thus has priority over the "Vermilion Creek series" of King and the "Bitter Creek group" of Powell. In 1907 the western part of the Little Snake River coal field was examined by Ball. ${ }^{5}$ In 1907 and 1908 Schultz ${ }^{6}$ mapped in detail the coal-bearing formations of the Rock Springs uplift. As a result of this work and of later reconnaissance to the south and east, he prepared a map ${ }^{7}$ covering most of the area described in this paper.

\section{FIELD WORK.}

In 1921 and 1922 a large part of Moffat County, Colo., and a few townships in southern Sweetwater County, Wyo., were examined by parties in charge of the senior writer. He was assisted in 1921 by K. K. Landes, in 1922 by James Gilluly, and in both seasons by the junior writer. Mapping was done largely by means of plane tables and telescopic alidades, on a system of triangulation extended westward and northwestward from the Craig quadrangle, Colorado. Isolated structural and areal features were mapped by means of stadia or pace traverses according to the degree of refinement desired. The mapping was tied to section corners at numerous points.

The geologic map (Pl. XXIV) accompanying this report is compiled from the work of Ball,

${ }_{5}^{5}$ Ball, M. W., The western part of the Little Snake River coal field, Wyo.: U. S. Geol. Survey Bull. 341, pp. 243-255, 1909.

${ }^{6}$ Schultz, A. R., The northern part of the Rock Springs coal field, Sweetwater County, Wyo.: U. S. Geol. Survey Bull. 341, pp. 256-282, 1909; The southern part of the Rock Springs coal field, Sweetwater County, Wyo.: U. S. Geol. Survey Bull. 381, pp. 214-281, 1910.

7 Schultz, A. R., Oil possibilities in and around Baxter Basin, in the Rock Springs uplift, Sweetwater County, Wyo.: U. S. Geol. Survey Bull. 702, pl. 1, 1920. 
Schultz, and Sears. The location of the area is shown in Figure 9.

\section{ACKNOWLEDGMENTS.}

The writers gratefully acknowledge the cordial assistance and hospitality given by the local ranchers, especially Messrs. Sparks. Crozier, and Grounds.

\section{TOPOGRAPHY.}

In the southwestern part of the area mapped Cold Spring Mountain and other ridges on the north flank of the Uinta Mountains rise to an altitude of about 8,500 feet above sea level. To the north, northeast, and east is the Green River Basin, separated by the Rock Springs uplift into the Bridger Basin on the west and the Washakie and Sand Wash basins on the east. Although the Green River Basin is of less

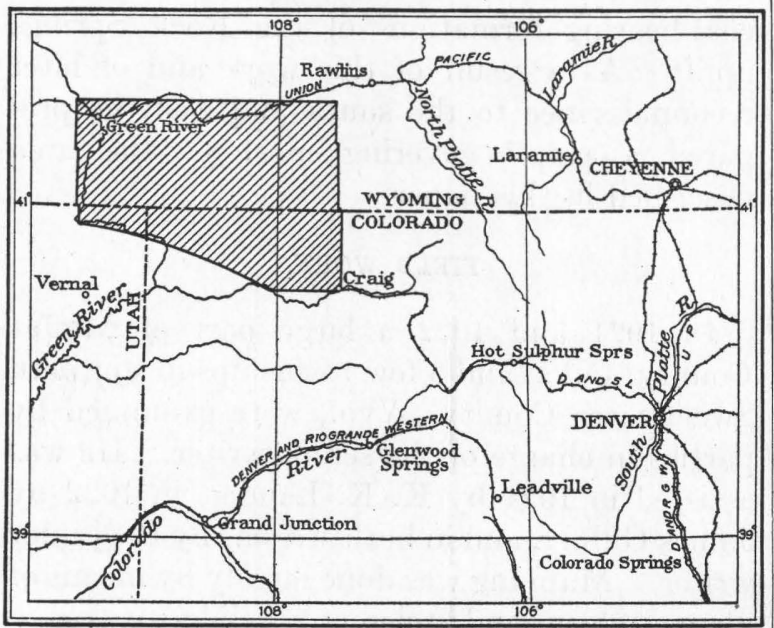

Figure 9.-Index map showing location of area in northwestern Colorado and southern Wyoming.

altitude than the Uinta Mountains it contains here and there high cliffs and isolated peaks; the highest point is Diamond Peak, 9,925 feet above sea level.

The major stream of the area mapped is Green River, which flows southward along its western margin. Green River, with its main tributaries, Bitter and Vermilion creeks, drains the Rock Springs uplift and a large part of the Washakie Basin. Across the southeast corner of the area runs Little Snake River, which, with its tributaries, Sand and Powder washes, drains the Sand Wash Basin and part of the Washakie Basin.

\section{STRATIGRAPHY. WASATCH FORMATION.}

The Wasatch deposits were named by Hayden ${ }^{8}$ because of their excellent exposures on the eastern slopes of the Wasatch Mountains. Their lithologic character in that region is illustrated by his brief description of their appearance in Echo and Weber canyons, Utah, where the formation consists of 1,500 to 2,000 feet of conglomerate. In a later report Hayden ${ }^{9}$ described this section more fully, noting the large size and well-rounded shape of the boulders and the predominant red color of the sandstones that make up the lower 500 to 800 feet of the formation. He noted also the rapid lateral changes near the base from fine sand to coarse conglomerate.

It is perhaps unfortunate that the name was taken from the Wasatch Mountains, where the formation has a lithologic character very different from that shown in most other areas. Hayden ${ }^{10}$ described the Wasatch at Carter Station, Wyo., as consisting of pink, red, and purple indurated sandy clays, alternating with gray and reddish sandstones; this description is more applicable to the formation throughout most of its area of distribution. Hayden believed that the beds were deposited in large fresh-water lakes.

Within the area mapped by the writers in 1921-22 the Wasatch consists chiefly of variegated clay shale and irregular, crudely bedded sandstone. The predominant colors of the clay shale are red and gray, commonly banded with yellow, lavender, pink, brown, pale green, drab, and other shades. Most of the sandstone is gray, buff, or dark brown; a few beds are white, pink, or red. The materials of the sandy beds range in size from very fine grains to coarse grits, and locally the sandstone grades into conglomerate carrying boulders as much as 6 feet in diameter.

In the Vermilion Creek basin the middle part of the Wasatch contains a few beds of coal, fissile carbonaceous shale, shell marl, and many more beds of sandstone than elsewhere in the field.

In general the Wasatch formation weathers into typical badlands that support little or no vegetation. Topography of this kind is varied

8 Hayden, F. V., U. S. Geol. and Geog. Survey Terr. Third Ann. Rept., p. 91, 1869.

Idem, Fourth Ann. Rept., pp. 147, 155-156, 1871.

10 Idem, p. 147. 


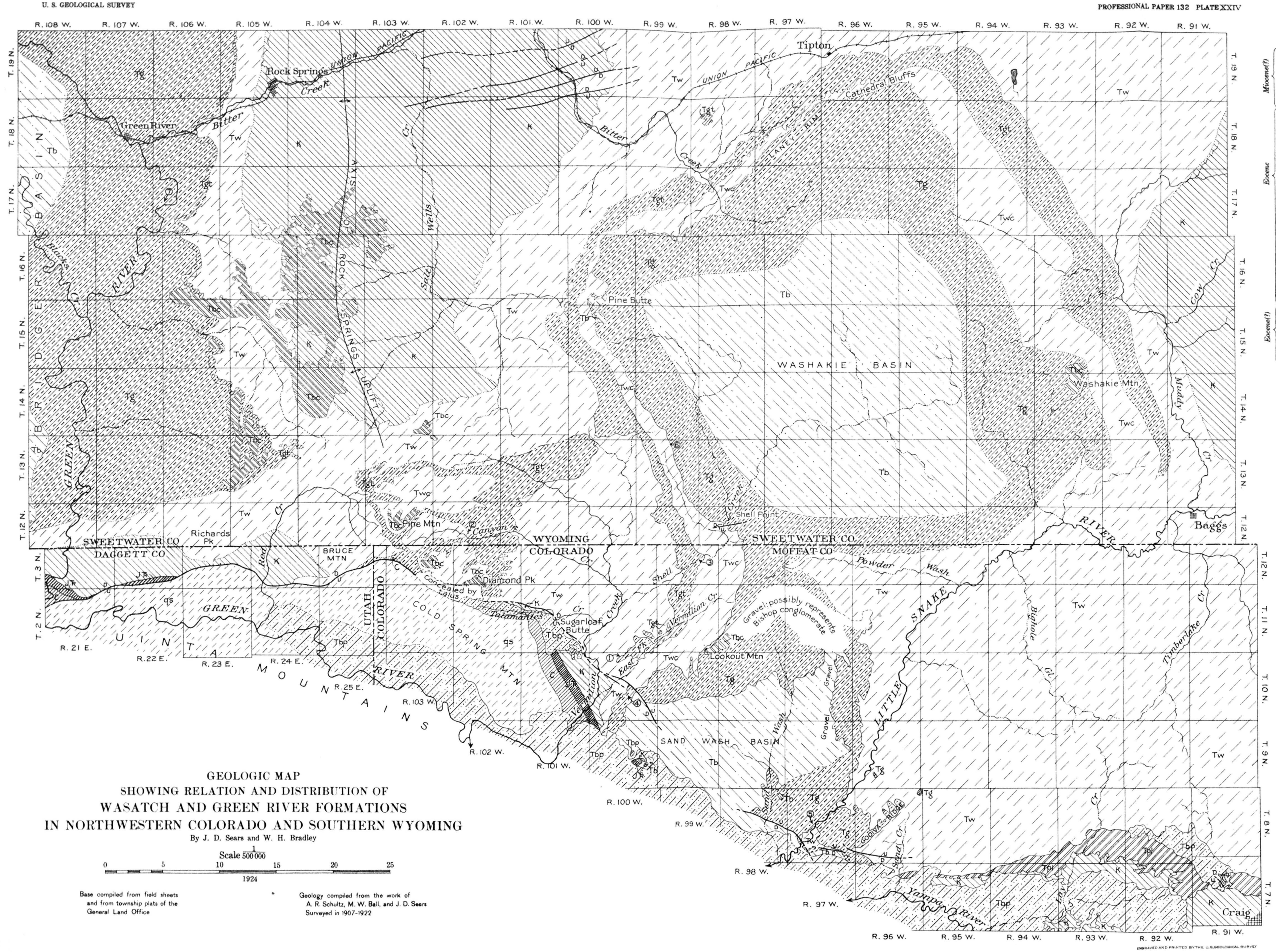


by low escarpments and benches where the sandstone is comparatively resistant.

\section{GREEN RIVER FORMATION.}

Remarkable exposures along Green River led Hayden ${ }^{11}$ to apply the name of that stream to the series of shale and sandstone overlying his Wasatch "group." The type locality of the formation is at the town of Green River, Wyo., where, according to Winchester, ${ }^{12}$ an incomplete section has a thickness of 755 feet. Other sections near by, ${ }^{13}$ in Tps. 17 and $19 \mathrm{~N}$. R. 106 W., show a thickness of approximately 1,350 feet. In all these sections a coarse, massive brown sandstone, 125 to 245 feet thick (the "Tower sandstone" of Powell), is included in the top of the formation. The remainder of the formation at the type locality consists almost entirely of finely laminated shale, some of which is rich oil shale. A few beds of thin platy sandstone and sandy shale occur at wide intervals in these sections. A very striking feature of the Green River in this part of the field is its bluish-white color on weathered surfaces.

Farther southeast, in the outcrops surrounding the Washakie and Sand Wash basins, the formation shows a somewhat different lithology. The "Tower sandstone" of Powell was not recognized by the writers in the southern part of this area, but it may be represented by one or more of the sandstones in the upper part of their Green River. The contact between this formation and the overlying Bridger was difficult to determine; it was drawn in the field at the horizon considered to mark most plainly a change in conditions of sedimentation. This mapping includes at the top of the Green River about 135 feet of beds that resemble somewhat the overlying as well as the underlying rocks. The Green River in this part of the field is about 1,200 feet thick and consists principally of finely laminated shales, many of which are very limy, and some beds of low-grade oil shale. The formation weathers to a characteristic buff color. In the upper 500 or 600 feet there is a greater amount of clay shale and thin-bedded to massive sandstone. A few thin beds of oolitic limestone, generally silicified, and calcareous alga reefs are scattered through the section.

\footnotetext{
${ }^{11}$ Hayden, F. V., U. S. Geol. and Geog. Survey Terr. Third Ann. Rept., p. $90,1869$.

12 Winchester, D. E., Oil shale of the Rocky Mountain region: U. S. Geol. Survey Bull. 729, p. 125, 1923.

13 Idem, pp. 124-126.
}

The Green River formation is peculiarly resistant to weathering and rises in high, steep cliffs of monotonous buff, gray, or bluish-white tints, contrasting sharply with the brightly colored badlands of the Wasatch. Almost as striking is the contrast between the Green River and the overlying Bridger, which weathers into fantastic badlands of ash or bluish gray, varied by dark-green and light-bluish sandstones and a few patches of red and orangecolored clay shale.

\section{STRUCTURE.}

The southern margin of the field is the north flank of the Uinta Mountain-Axial Basin arch. West of Little Snake River the Eocene beds, dipping away from the mountains, rest with marked angular unconformity upon the upturned edges of Mesozoic rocks, showing that uplift of the Uinta region both preceded and followed Eocene deposition. Farther southeast no angular unconformity is found below the Wasatch and Green River, a fact which indicates that movement of the Axial Basin anticline began after the end of Eocene time.

North of this great uplift is the broad Green River Basin, which in the area here mapped is divided by the north-south Rock Springs uplift into two synclinal depressions. The western depression, known as the Bridger Basin, is partly within this area. The eastern depression is separated by one or two eastwest arches into the Washakie Basin on the north and the Sand Wash Basin on the south.

The present southern edge of the Eocene outcrops is determined partly by the original limits of deposition and partly by structure. At the southwest it is marked in part by the great Uinta fault, which extends for many miles westward from the northwest corner of Colorado; some if not all of the movement along this fault was post-Wasatch. It is possible that the fault between the Cretaceous and the Wasatch rocks, extending from Diamond Peak southeastward to a point beyond East Fork of Vermilion Creek, is a continuation of the Uinta fault, but their relation is concealed by recent débris.

From Vermilion Creek southeastward to Sand Creek the margin of Eocene deposits is marked by a zone of en échelon faults and sharp anticlines. These and other faults farther out in the basin have no bearing on the character and relations of the Wasatch and Green River and need not be described here. 
ORIGIN AND RELATIONS OF THE WASATCH AND GREEN RIVER FORMATIONS.

\section{THE UINTA MOUNTAINS AS A SOURCE OF MATERIAL.}

Powell ${ }^{14}$ noted the occurrence of thick conglomerates in the basal part of his "Bitter Creek group" (Wasatch formation) on the north side of the Uinta Mountains from Richards Peak, Wyó., to a point east of Bruce Mountain, Colo. The conglomerate consists of boulders and pebbles of sandstone and limestone; in the vicinity of Richards Peak the limestone boulders contain Jurassic fossils. From these facts Powell inferred that in Wasatch time erosion of the Uinta Mountains had in places reached the Carboniferous rocks; that the conglomerate referred to was formed from sandstone and limestone of Mesozoic age, and, to a lesser extent, of Carboniferous age; and "that the badland rocks of Mesozoic age were carried from the Uinta region and redistributed as badland beds of the Bitter Creek period." ${ }_{15}$ Powell ${ }^{16}$ noted also that near the Uinta uplift the Green River formation "is much thickened, and the shales are replaced by sandstones and conglomerates of fine pebbles"; from this he inferred that the Green River was "derived from the Uinta region, and that the material was supplied from limestones and sandstones of Carboniferous age."

Additional evidence pointing to the Uinta Mountains as a source of material was collected by the writers in 1922. Conglomerates in both the Wasatch and the Green River are thickest and carry the largest boulders near the mountains and thin rapidly toward the basin. The most conspicuous example is at Sugarloaf Butte, in secs. 15 and 16, T. 11 N., R. $101 \mathrm{~W}$., where there is in the lower part of the Wasatch an alternating series, 150 to 200 feet thick, of very coarse conglomerate, grit, and lenses of coarse cross-bedded friable buff to white sandstone. Most of the boulders are well rounded by stream action, but some are angular and subangular; the largest boulders are 6 feet in diameter. (See Pl. XXV, A.) This notable aggregation of coarse detritus, in which there is only the crudest kind of strati-

${ }^{14}$ Powell, J. W., Report on the geology of the eastern portion of the Uinta Mountains, pp. 162-164, U. S. Geol. and Geog. Survey Terr., 2d div., 1876.

${ }^{15}$ Idem, p. 165.

${ }_{16} \mathrm{Idem}$, p. 166 fication, grades laterally within less than a mile to the north and east into carbonaceous shale, shell marl, and coarse but regularly bedded sandstone-the typical Wasatch assemblage of this vicinity. The interfingering of these several types is clearly exposed eastward in the bluffs along Talamantes Creek and to the north in deep tributary gulches. There can be no doubt that the material was derived from the Uinta uplift, as the conglomerate thins away from the mountains and consists principally of gray cherty limestone identical with the massive Carboniferous limestone now exposed high on the flank of Cold Spring Mountain, less than 2 miles to the southwest. Evidently the Carboniferous rocks of the uplift were being eroded during at least a part of Wasatch time.

Westward from Sugarloaf Butte the Wasatch contains near its base several beds of conglomeratic sandstone consisting of abundant white sugary-textured quartzite pebbles and boulders as much as 8 inches in diameter in a white or gray sandy matrix. These white quartzites are very similar to the Weber and older Pennsylvanian quartzitic sandstones exposed in the Uinta Mountains. Eastward from Sugarloaf Butte as far as East Fork of Vermilion Creek conglomerates in the lower Wasatch are characterized by pebbles of black chert; the source of the chert is unknown, but the pebbles strongly resemble those of the Dakota in color, roundness, and high polish, and they may have been reworked from that formation.

Eastward from Godiva Ridge several conglomeratic sandstones near the base of the Wasatch contain many well-rounded chert pebbles less than half an inch in diameter; these pebbles, predominantly white and to a lesser extent red and black, may have been derived either from the Uinta Mountains or from the Park Range, to the east.

The development of conglomerate close to the mountains is illustrated also in the Green River formation. Along Canyon Creek from sec. 18, T. 12 N., R. 101 W., westward to Pine Mountain the upper 300 feet of the Tipton tongue of the Green River formation is represented by massive medium to coarse grained sandstones separated by very thin partings of hard greenish shale. In these sandstones, especially in the upper ones, are zones of 
pebbles and boulders as large as 6 inches in diameter, of white and brown quartzite, angular red chert, hard shale, and cherty limestone; a few boulders consist of red quartzite lithologically identical with the red quartzite that forms the core of the Uinta Mountains. Schultz ${ }^{17}$ noted these conglomeratic sandstones on Canyon Creek and says: "Upstream on Ruby Creek toward the mountains the percentage of conglomerate and the size of the pebbles rapidly increase. Within a mile boulders as large as 2 feet are encountered." Northward from the Canyon Creek coal mine, in sec. 17, T. 12 N., R. 101 W., the conglomeratic sandstone grades laterally into gray fissile shale that is characteristic of the Tipton tongue.

Another type of evidence pointing to the Uinta Mountains as a source of material may be summarized as follows. An erosional window in the Browns Park formation, in T. 9 N., R. 100 W., exposes the Bridger resting with marked angular unconformity upon Mancos and older Mesozoic rocks dipping northeastward on the flank of the Uinta Mountain arch. The Bridger is very conglomeratic, the boulders consisting largely of gray cherty limestone containing Carboniferous fossils. Inasmuch as a few miles farther north there is no angular unconformity between the Bridger and Green River, the fact that in T. 9 N., R. 100 W., the Bridger rests directly upon Mesozoic rocks seems to show that the Wasatch and Green River were not deposited this far south, and that the Bridger was laid down as an overlap beyond the margins of the older Eocene beds. This conclusion, together with the conglomeratic nature of the Bridger, indicates that the east end of the Uinta Mountains was never buried under Eocene beds but was the site of erosion that furnished the Eocene sediments. On the other hand, it seems probable that the Wasatch and Green River formations (and possibly the Bridger) of the Green River and Uinta basins were continuous around the east end of the mountains; this inference is drawn from the narrow interval (14 miles) now separating the northern and southern Wasatch and Green River outcrops east of Cross Mountain and from the lack of angular unconformity between

17 Schultz, A. R., Oil possibilities in and around Baxter Basin, in the Rock Springs uplift, Sweetwater County Wyo.: U. S. Geol. Survey Bull. 702, p. 31, 1920.
Wasatch and Cretaceous rocks in the Axial Basin anticline, showing that that arch was not uplifted at the earliest until after Green River time.

BROAD VARIATIONS AWAY FROM THE SOURCE.

In addition to the local changes within the formations near the mountains, there are large-scale lateral variations in the sediments farther out in the basin of deposition.

In the basin of Vermilion Creek the upper part of the Wasatch is principally variegated clay shale in which red is the predominant color. The lower part consists largely of gray and buff clay shale and sandstone; it includes also some brightly colored clay shale, a few beds of coal which in places are thick enough to be mined for local use, thin-bedded carbonaceous shale and interbedded shell marl (which superficially resemble the Green River formation), and at least one calcareous alga reef. In the vicinity of East Fork of Vermilion Creek, northeastward from sec. 4, T. 10 N., R. $100 \mathrm{~W}$., a zone of clay shale and sandstone near the top of the lower Wasatch grades laterally into gray fissile shale of Green River appearance. Farther north this zone includes beds of low-grade oil shale; it thickens from about 200 feet in sec. 3, T. 10 N., R. 100 W., to nearly 400 feet in secs. 27 and $28, T$. 12 N., R. $99 \mathrm{~W}$. The method of thickening is illustrated at the base of the fissile shale in secs. 34 and 35, T. 11 N., R. 100 W., where a long wedge of papery, low-grade oil shale replaces toward the north a band of gray and buff clay shale, and the whole Green River zone thickens 100 feet in about a mile. Similar examples were noted elsewhere along the outcrop.

Thus the Wasatch is split northward into two parts by a wedge of very different material. The thickness of the lower part is unknown, as the base is not exposed. The upper part, called by Schultz ${ }^{18}$ the Cathedral Bluffs red beds member of the Green River formation, is 1,200 feet thick at Lookout Mountain and 600 feet thick northwest of the Washakie Basin; westward and northwestward, according to Schultz, it merges laterally into typical Green River shale. The wedge of fissile shale and oil shale was named by Schultz ${ }^{19}$ the Tipton shale member of the Green River formation.

18 Idem, p. 28. 19 Idem, p. 30. 
On the east side of the Washakie-Sand Wash depression a similar change northward occurs in the Wasatch. Godiva Ridge is capped by the main body of the Green River formation, which in this area is the Laney shale member. Below this is exposed the entire Wasatch formation, 5,600 feet thick, consisting of brightly colored clay shale and subordinate. sandstone, with no beds of Green River type. North of Baggs, Wyo., the Tipton tongue of the Green River enters in the midst of the Wasatch beds, thickens northward, and, encircling the north end of the Washakie Basin, unites with the Tipton to the west. Thus the outcrop of the Tipton tongue has the shape of the letter $U$ with the open side toward the south. The Tipton lake may have extended southward to a line between Baggs and East Fork of Vermilion Creek; and there is a possibility that much of the Cathedral Bluffs tongue of red beds, deposited as this lake retreated, was derived from the east and southeast.

In contrast to the relations described above, Green River deposition on the east rim of the Bridger Basin was evidently not interrupted by a temporary regression of the lake, as the Wasatch and Green River show no interfingering, even close to the mountains. In this area the lake probably reached the foot of the mountains, but as the finely laminated shale and oil shale of the Green River indicate deposition in very quiet water, material must have been carried out from the mountains very slowly if at all.

On the rim of the Washakie-Sand Wash depression the main body of the Green River formation (Laney shale member) undergoes a very gradual northward change. Near the mountains it is prevailingly buff and much of its shale is limy and poor in oil-yielding organic matter. Although sandstones are numerous, only one conglomerate was observed. This conglomerate, about 5 feet thick, contains small-subangular pebbles of black and green chert and of coarse-grained red quartzite, some grains of glassy quartz, and a few compact clay balls. The pebbles average a quarter of an inch in diameter; a few pebbles of black chert are an inch in diameter. This conglomeratic lens, near the top of the Laney shale member in T. 9 N., R. 100 W., passes rapidly northward into a coarse-grained sandstone with a limy cement. Just west of Little Snake River, near the center of T. 8 N., R. 97 W., two or three thin beds of coal and numerous beds of partly humified plant remains occur in the Laney shale several hundred feet above the base. The coal beds are bony and very lenticular, ranging from a few inches of carbonaceous material to beds 3 feet thick: Toward the north the Green River formation contains fewer and thinner sandstones, and its buff color changes gradually to the more characteristic bluish-white tone, probably owing to an increasing richness of the oil shale.

\section{NOMENCLATURE.}

The early explorers believed that the Green River formation is not only different from the Wasatch in lithology but is also distinctly younger throughout. Such a belief is justified in the Bridger Basin, where the Wasatch was followed by continuous Green River deposition. Farther east, however, in the WashakieSand Wash depression, this belief led them to draw the boundary at the base of the beds later named Laney shale member by Schultz, thus including in the Wasatch the deposits here called the Tipton tongue of the Green River formation and the Cathedral Bluffs tongue of the Wasatch formation. The boundary was drawn at the same horizon by Schultz ${ }^{20}$ in his reports on the coal fields of the Rock Springs uplift. In a later report, however, Schultz ${ }^{21}$ described the northwestward gradation of his Cathedral Bluffs red beds member into shale of Green River type and suggested that his Tipton shale member might die out toward the southeast, causing an interfingering of the two formations. He believed that the Green River west of the Rock Springs uplift is the time equivalent of all beds east of the uplift between the base of the Tipton tongue and the base of the Bridger, and hence he treated the Tipton tongue and the Cathedral Bluffs tongue as members of the Green River formation.

${ }^{20}$ Schultz, A. R., The northern part of the Rock Springs coal field, Sweetwater County, Wyo.: U. S. Geol. Survey Bull. 341, pp. 256-282, 1909; The southern part of the Rock Springs coal field, Sweetwater County, Wyo.: U. S. Geol. Survey Bull. 381, pp. 214-281, 1910.

${ }_{21}$ Schultz, A. R., Oil possibilities in and around Baxter Basin, in the Rock Springs uplift, Sweetwater County, Wyo.: U. S. Geol. Survey Bull. 702, pp. 25, 28-31, 1920. 
Although the time equivalence suggested by Schultz is essentially correct, the writers believe that his classification does not adequately express the time and depositional relations of the Wasatch and Green River. The interfingering of these formations, now proved to exist, may be better indicated by the use of the term "tongue," introduced by Stephenson. ${ }^{22}$ The names Cathedral Bluffs tongue of the Wasatch formation and Tipton tongue of the Green River formation are therefore here used to re- arch and carried great amounts of sediment out over the lowlands. Alluvial fans of poorly sorted boulders were built up at the foot of the mountains by torrential streams; flood-plain silts and stream-channel deposits, which later became colored clay shale and coarse, irregular sandstone, were laid down farther out in the basin. Here and there swamp conditions permitted the accumulation of plant remains, which later became carbonaceous shale and coal. To the east and west these deposits of

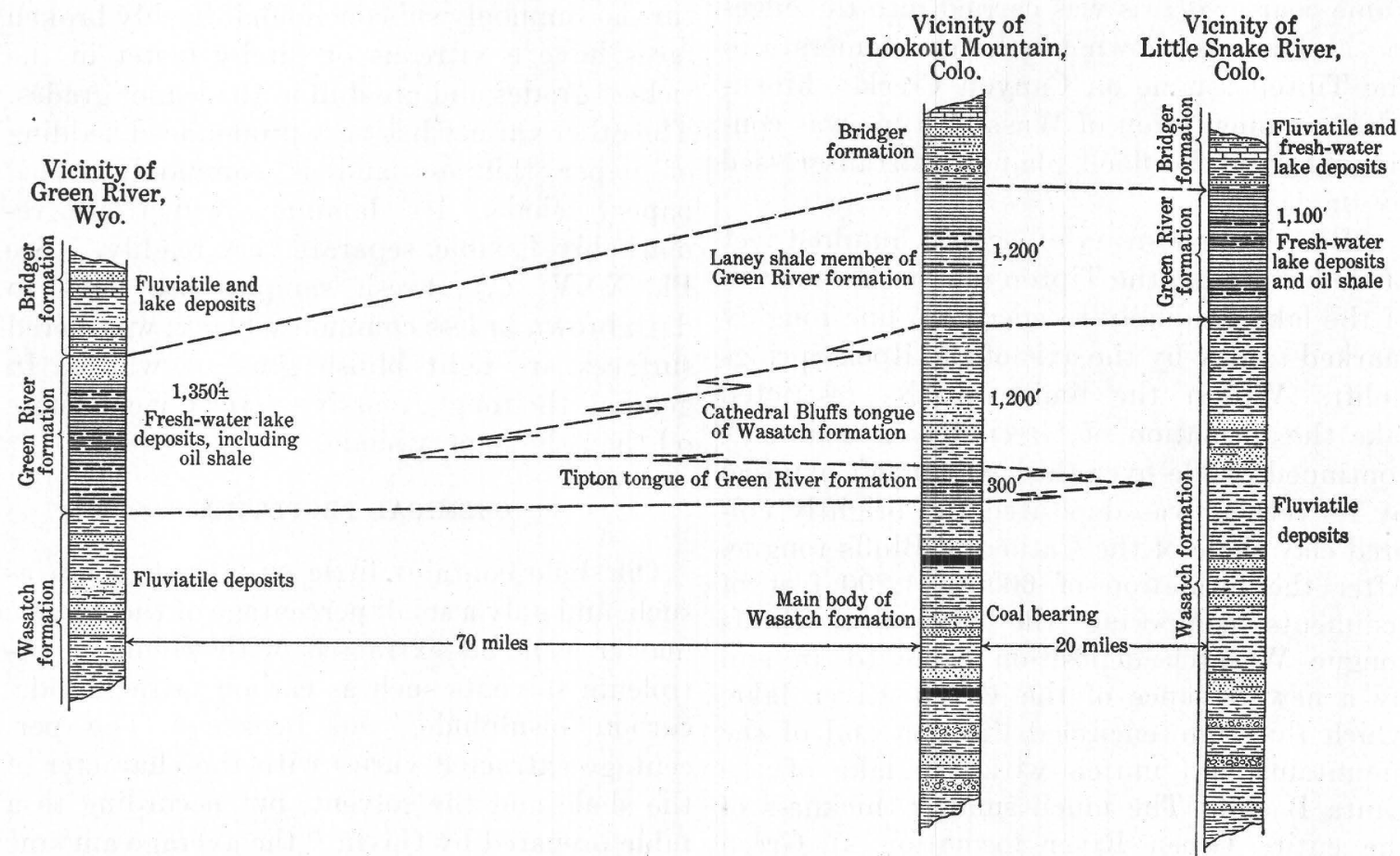

FIGURE 10.-Sections from northwest to southeast in the Green River Basin, Wyoming and Colorado, showing interfingering of the Wasatch and Green River formations.

place the members of Schultz. The relations of these tongues are shown diagrammatically in Figure 10.

\section{SUMMARY OF GEOLOGIC HISTORY.}

The geologic events bearing on the deposition and relations of the Wasatch and Green River in this area may be summarized as follows:

After Cretaceous time the Mesozoic and older rocks were lifted many thousands of feet in the Uinta Mountain arch, and on the north side part of this movement resulted in great faulting. Streams began a vigorous attack on the Mesozoic rocks forming the surface of the

${ }^{22}$ Stephenson, L. W., Tongue, a new stratigraphic term, with illustrations from the Mississippi Cretaceous: Washington Acad. Sci. Jour., vol. 7, pp. 243-250, 1917. early Wasatch time merged with material brought from the Park and Wasatch ranges. As erosion cut deeper into the mountain mass, older rocks were exposed and fragments of Carboniferous limestone were carried into the basin. Scattered shallow ponds swarmed with organisms such as Unio and Goniobasis, as is attested by the abundant shell marl interspersed in lenses of finely laminated carbonaceous shale. The increasing thickness of the Wasatch deposits caused an encroachment upon the lower flanks of the mountains, as illustrated on Vermilion Creek by the overlap of the Wasatch upon beds ranging in age from Mesaverde to Twin Creek. East of the Uinta Mountains the Wasatch was laid down upon practically horizontal Cretaceous rocks. 
Over these flood-plain deposits spread gradually a broad, shallow lake. Toward the west this lake reached the foot of the Uinta Mountains; here its transgression marked the end of Wasatch sedimentation, as the lake maintained its position until the end of Green River time. Farther east the margin of the lake was a line between East Fork of Vermilion Creek and Baggs, Wyo. Into the quiet waters of this lake was transported fine sediment, which became mixed with varying amounts of organic matter and formed the gray fissile shale and oil shale of Green River type. Some coarser débris was carried into the edges of the lake, as shown by the conglomerate in the Tipton tongue on Canyon Creek. Meanwhile sedimentation of Wasatch type was continuing over the flood plains not transgressed by the lake.

After the deposition of several hundred feet of shale, forming the Tipton tongue, the margin of the lake gradually receded to a line roughly marked to-day by the axis of the Rock Springs uplift. Within the limits of the restricted lake the formation of Green River sediments continued, while over the fine silt left exposed by its retreat was deposited the brightly colored clay shale of the Cathedral Bluff's tongue. After the formation of 600 to 1,200 feet of sediments composing the Cathedral Bluffs tongue Wasatch deposition came to an end by a new advance of the Green River lake, which this time encircled the east end of the mountains and united with the lake of the Uinta Basin. The much smaller thickness of the entire Green River formation at Green River, Wyo., compared with the thickness of its age equivalents - the Tipton and Cathedral Bluffs tongues and Laney shale member (possibly including representatives of the "Tower sandstone" and plant beds of Powell)-at Lookout Mountain, may be partly accounted for by a gradual southeastward tilting that may have been an important factor in the second transgression of the Green River lake.

Later folding and faulting have changed the attitude of the Wasatch and Green River but have not affected their relations.

Two questions may be outlined as problems for future study. What was the mode of disappearance of the Green River lake? Are the earliest Green River beds of the Uinta Basin the age equivalents of the basal Tipton tongue or the basal part of the Laney shale member?

\section{OIL SHALE IN THE GREEN RIVER FORMATION.}

\section{PHYSICAL PROPERTIES.}

The oil shale in the Green River formation may be divided into two distinct varieties, between which there are many gradations. One variety is hard and tough. On fresh surfaces it is chocolate-brown to black and generally shows no distinct lamination. When weathered it is predominantly of a bluish-white color, and its finely laminated structure is indicated by the alternation of thin dark-gray bands with bluishwhite layers. (See Pl. XXV, B.) The fracture is commonly subconchoidal; freshly broken faces have a vitreous or pitchy luster in the richest grades and are dull in the leaner grades. The other variety has very pronounced bedding of paper thinness and is commonly called papery shale. Its laminae, which are remarkably flexible, separate very readily. (See Pl. XXV, C.) Fresh samples are light to dark brown or less commonly black; weathered surfaces are light bluish gray or white. In general, the tough, massive variety yields more oil than the papery shale.

\section{CHEMICAL PROPERTIES.}

Oil shale contains little or no petroleum as such, and only a small percentage of the organic matter can be extracted with common petroleum solvents such as carbon tetrachloride carbon bisulphide, and benzene. The per centage extracted varies with the character of the shale and the solvent, but according to a table prepared by Gavin ${ }^{23}$ the average amount extracted by six solvents from three samples of Green River shales was only 1.3 per cent of the weight of the samples.

Upon destructive distillation the organic matter in the shale yields a crude oil. According to Steuart, ${ }^{24}$ Prof. Crum Brown gave the name "kerogen" to this organic matter of indefinite and variable chemical composition.

The economic value of the shale depends upon the character of the kerogen and the proportions of kerogen and clastic mineral matter. McKee and Goodwin ${ }^{25}$. show that

${ }^{23}$ Gavin, M. J., Oil shale-an historical, technical, and economic study: U. S. Bur. Mines Bull. 210, p. 28, 1922.

${ }^{24}$ Steuart, D. R., Oil shales of the Lothians, pt. 3, The chemistry of the oil shales, 2d ed., p. 159, Scotland Geol. Survey Mem., 1912.

${ }_{25}$ McKee, R. H., and Goodwin, R. T., A chemical examination of the organic matter in oil shales: Colorado School of Mines Quart., vol. 18, No. 1, pp. $8,20,1923$. 


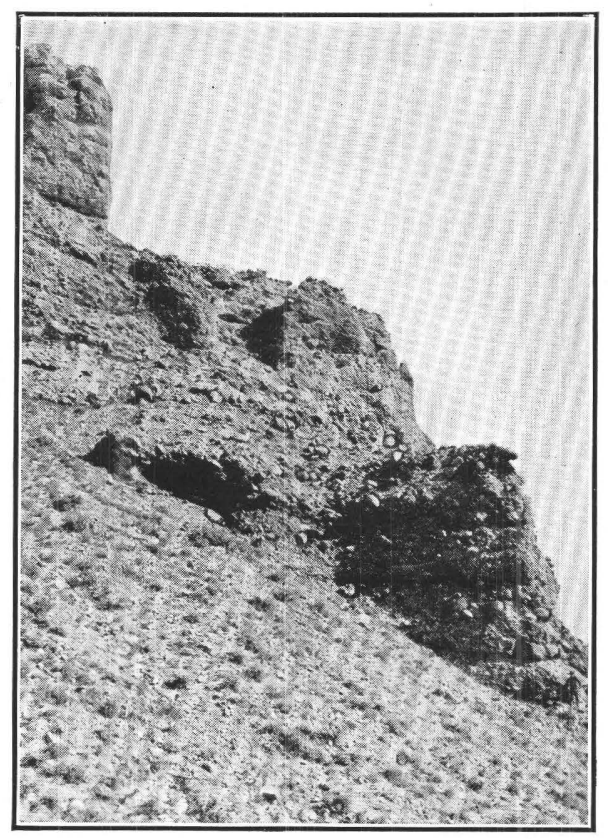

A. CONGLOMERAte in the lower Part of THE WASATCH FORMation at SUGARLOAF BUTTE, SEC. 15, T. 11 N., R. 101 W., COLO.

Compare size of boulders with height of man on right side of photograph

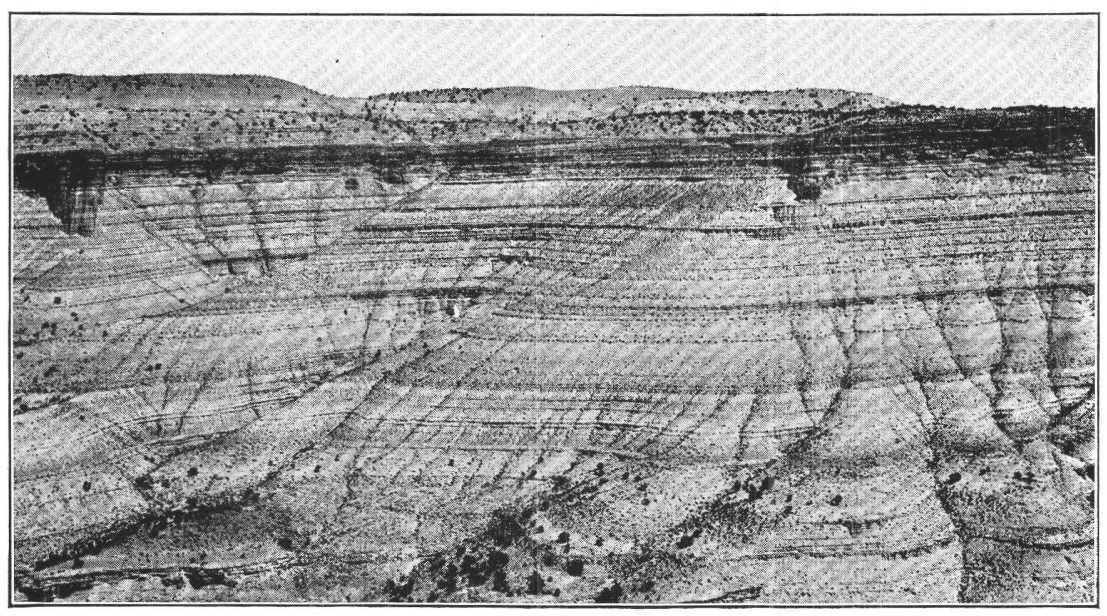

B. OIL SHALE IN THE GREEN RIVER FORMATION,' SHOWING CHARACTERISTIC THIN, REGULAR BEDDING

Photograph by D. E. Winchester

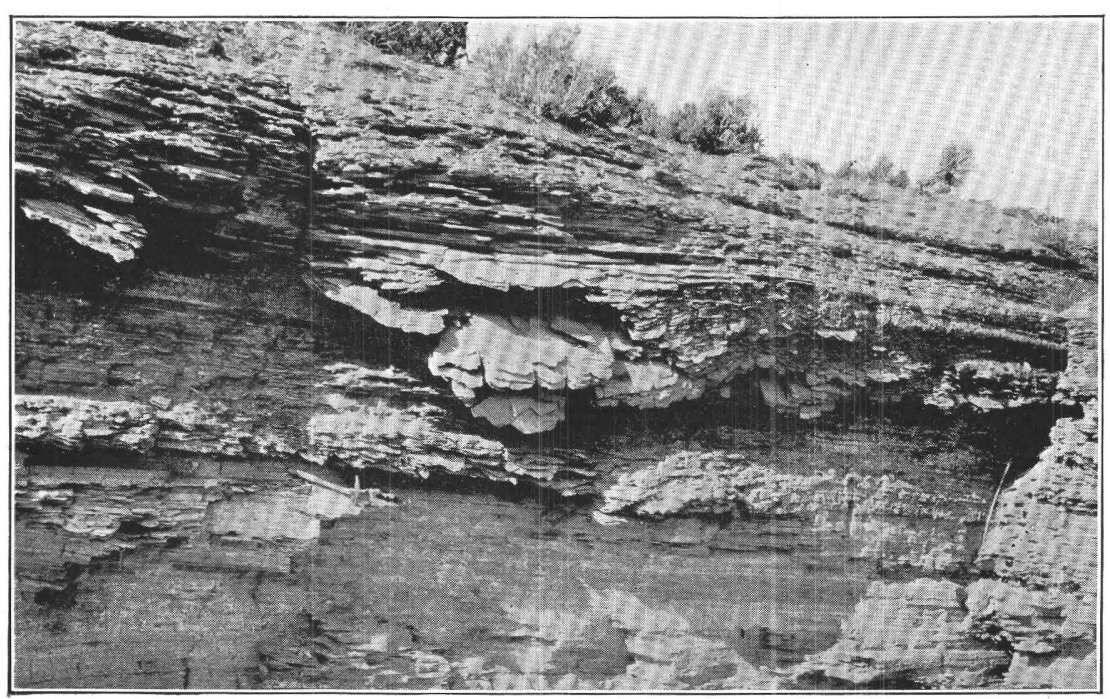

C. PAPERY OIL SHALE, SHOWING FLEXIBILITY

Photograph by D. E. Winchester 

the chemical composition of the kerogen and hence of the oil distilled from it differs in different shales and even from place to place in the same formation. For example, shale oil from the Green River formation in Colorado has a mixed paraffin and asphalt base, whereas shale oil from a locality in Utah has an asphaltic base. The yield of oil is to some degree dependent upon the chemical composition of the shale, but is determined far more by the amount of kerogen present.

\section{EFFECT OF VARYING CONDITIONS OF FORMATION}

Researches of numerous careful students ${ }^{26}$ indicate that kerogen was formed by the accumulation in fresh water of spore exines, pollen grains, the more resinous parts and somewhat macerated cuticles of larger plants, and the remains of various types of algae, particularly the more gelatinous and filmy types. The low orders of plant life, both sessile and planktonic, the drift material, and the parts of higher plants would be distributed in varying amounts through a body of fresh water according to depth, currents, wave action, source of supply of extraneous material, prevailing winds, and other factors. Where clastic material was being carried into the lake the organic content of the shale formed would be relatively smaller and the value of the shale as an oil producer would be lessened. Where the organic débris could accumulate without much influx of inorganic material the resultant shale would be very much richer in kerogen.

From this reasoning it is easily understood why the oil shale of the Green River formation near the east end of the Uinta Mountains is of very low grade. Much clastic material was carried out from the mountains and deposited in the shoreward portion of the Green River lake; the proportion of included organic material was small. Farther out in the lake, and

${ }_{26}$ Bertrand, C. E., Les charbons humiques et les charbons des purins: Lille Univ. Trav. et Mém., vol. 6, Mém. 21, pp. 13-178, 1898; Conférences sur les charbons de terre: Soc. belge géol. Bull., vol. 11, p. 287, 1897. Davis, C. A., On the fossil algae of the petroleum-yielding shales of the Green River formation of Colorado and Utah: Nat. Acad. Sci. Proc., vol. 2, pp. 114-119, 1916; quoted in Winchester, D. E., Oil shale in northwestern Colorado and adjacent areas: U. S. Geol. Survey Bull. 641, p. 165, 1916; Oil shale of the Uinta Basin, northeastern Utah: U. S. Geol. Survey Bull. 691, pp. 46-47, 1918. Jeffrey, E. C., The nature of some supposed algal coals: Am. Acad. Arts and Sci. Proc., vol. 46, pp. 273-290, 1910. Thiessen, Reinhardt, and White, David, The origin of coal: U. S. Bur. Mines Bull. 38; pp. 199-203, 1913; Origin of certain oi shales: Econ. Geology, vol. 16, pp. 289-300, 1921. White, David, Late theories regarding the origin of oil: Geol. Soc. America Bull., vol. 28, p. $730,1917$. also near shore at places where little clastic material was being supplied, the proportion of organic débris was much larger; and the shale is far richer in the oil-yielding kerogen. The variation is strikingly shown by comparison of sections of the Tipton tongue in T. $10 \mathrm{~N}$, R. 100 W., Colo., and T. 12 N., R. 102 W., Wyo., with a section on Shell Creek in T. 12 N., R. 99 W., Colo.; it is indicated also by comparison of sections of the Laney shale member in T. 8 N., R. 97 W., and T. 10 N., R. 100 W., with those in T. 13 N., R. 99 W., and T. 17 N., R. 106 W. These sections, given on following pages, show a gradation northward; as the sandstones and the more limy and sandy shales disappear the percentage and richness of oil shale insrease.

\section{MEASURED SECTIONS AND TESTS.}

The following sections, measured by the writers except as otherwise noted, indicate the character of the formation at different localities and present more detailed data concerning lateral changes. Results of distillation tests are given opposite the descriptions of the beds sampled. Beds described as low-grade oil shale yield less than 10 gallons to the ton.

Sections of Tipton tongue of Green River formation in Moffat County, Colo., and Sweetwater County, Wyo.

Locality 1, sec. 3, T. 10 N., R. 100 W.

Sandstone, buff, hard, medium grained ...-

Sandstone, brown, thin bedded, interbedded with hard gray-green shale.....Sandstone, gray, massive, medium grained. Shale, gray-green, platy _.............. Sandstone, brown, medium grained ...... Shale, greenish brown, platy to lumpy ... Sandstone, brown, platy, medium grained_ Shale, gray-green, platy _............ Sandstone, reddish brown, medium grained, undulating bedding planes.............

Shale, greenish brown, sandy, platy ......

Sandstone, brown, very fine grained.....

Shale, gray-green, platy _................

Sandstone, brown, very fine grained.....

Shale, gray-green, platy _.............

Sandstone, brown, very fine grained . . . . -

Clay shale, light gray .................

Shale, gray-green, soft, platy

Sandstone, yellow-brown, thin bedded, fine grained............................

Shale, gray-green, platy to lumpy _....... -

Shale, brown, carbonaceous, papery; trace of oil

Ft. in

26

21

28

26

2

8

3

3

16

86

Shale, gray to light brown, flaky .........

Shale, chocolate-brown, carbonaceous; trace of oil. 
Shale, gray, flaky

Sandstone, buff, cross-bedded, medium grained

Shale, brownish gray, papery; contains many humified plant fragments........

Sandstone, buff, cross-bedded; upper 3 feet platy with shaly partings..............

Shale, dark brown, papery, brittle, carbonaceous; contains abundant humified plant fragments .

Wasatch formation.

Locality 2, sec. 15, T. 12 N., R. 102 W.

Sandstone, brown, cross-bedded, very coarse grained, locally conglomeratic, carrying red and brown quartzite boulders as much as 5 inches in diameter -.

Sandstone, hard, gray; irregular thin bedding -

Sandstone, light gray, cross-bedded, medium to coarse grained..................

Sandstone, gray, very hard, thin bedded, fine grained

Interval concealed, probably fine-grained lumpy sandstone....................

Sandstone, cross-bedded, from medium grained to conglomeratic . . .

Sandstone, hard, fine grained . . . . . . . . . .

Sandstone, brown, massive, coarse grained - -

Sandstone, hard, massive, fine grained....

Sandstone, massive, coarse grained; carries a few pebbles...........................

Shale, hard, sandy, interbedded with thinbedded sandstone

Sandstone, platy, interbedded with thin, hard, impure limestones..............

Sandstone, hard, platy, very fine grained -

Sandstone, gray, soft, thin bedded to crossbedded, medium grained ...............

Sandstone, greenish gray, hard, irregularly bedded; contains numerous soft white

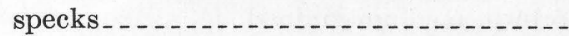

Sandstone, buff, massive, fine grained....

Sandstone, greenish gray, hard, irregularly bedded; contains numerous soft white

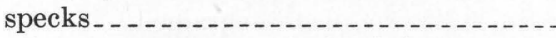

Sandstone, gray, cross-bedded, in part conglomeratic.

Sandstone, thin bedded, fine grained, interbedded with hard brown low-grade oil shale

Sandstone, basal 3 feet conglomeratic, carrying pebbles of white quartz, hard shale, red and gray chert, and limestone; remainder fine grained and irregularly thin bedded

Shale, very low-grade oil shale, interbedded with numerous fine-grained platy sand-

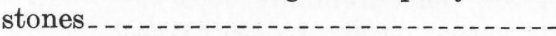

Sandstone, brown, slightly cross-bedded; carries subangular white and pink quartzite pebbles.
Ft. in.

Sandstone, blue-gray, soft, fine grained.-.Sandstone, light gray, very coarse grained, locally cross-bedded and conglomeratic..

Sandstone, massive to platy, medium to

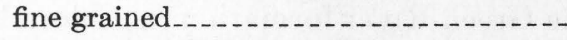

Shale, sandy, platy

19 Sandstone, greenish gray, massive, sugary textured, medium grained .........

Shale, sandy, interbedded with thin-bedded medium-grained sandstone..........-

Shale, hard, brown; low-grade oil shale; contains small limy concretions........-

Sandstone, soft, medium to coarse grained and slightly cross-bedded; several 6-inch partings of hard shale..............

Shale, laminated to lumpy; contains sandy

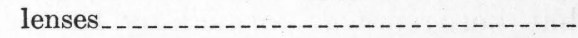

Sandstone, reddish brown, massive, medium

Shale, greenish gray, hard, lumpy

Shale, hard, brown; low-grade oil shale; weathers blue-gray _...............

ndstone, soft, medium to coarse grained.

Sandstone, thin bedded; interbedded with

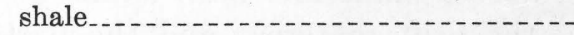

Sandstone, brown, medium grained.......

Shale, dark brown, laminated; low-grade oil shale.

6 Sandstone, brown, coarse grained........

Shale, hard, brown, massive; low-grade oil shale..............

Sandstone, brown, medium grained .......

Shale, chocolate-brown, hard, massive; lowgrade oil shale................

Sandstone, red-brown, massive to thin bedded, medium to fine grained; carries leaf impressions; numerous thin partings of sandy shale........

Shale, sandy, gray; few thin platy sand-

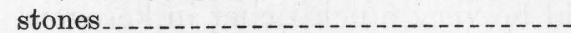

Shale, brown, papery; few thin sandstones;

trace of oil.....

Concretionary zone; probably calcareous alga reef lower part sandy clay shale.

Sandstone, brown, thin bedded, fine grained

Clay shale, hard, gray ................

Sandstone, brown, soft and friable, coarse grained.

Clay shale, blue-gray . .

Shale, papery; low-grade oil shale........

Clay shale, sandy, hard and lumpy .....-

Shale, brown, papery; low-grade oil shale.-

Clay shale, gray; few thin sandstones...--

Shale, chocolate-brown, papery; low-grade oil shale

Sandstone, limy; full of Goniobasis shells -

Gray and maroon clay shale of Wasatch formation.
Ft. in 
Locality 3, secs. 27 and 28, T. 12 N., R. 99 W.

Red and green clay shale and sandstone of the Cathedral Bluffs tongue of Wasatch formation.

Shale, greenish gray; upper part clayey; lower part laminated low-grade oil shale.

Sandstone, brown, soft, thin bedded, fine grained; ripple-marked at top

Shale, greenish gray, hard, laminated ....-

Sandstone, brown, thin bedded, fine grained, interbedded with sandy shale.

Shale, sandy, hard .....................

Sandstone, light gray, soft, thin bedded, interbedded with sandy shale..........

Shale, hard and sandy, interbedded with thin fine-grained micaceous sandstones. -

Sandstone, brown, hard, medium grained, in part cross-bedded; abundant mica flakes

Sandstone and interbedded bluish-gray shale; both micaceous...............

Zone of hard brown sandy concretions....

Sandstone, dark gray, much cross-bedded, fine grained; distinct parting planes of mica flakes.

Shale, light gray; few thin micaceous sandy lenses

Alga reef, calcareous. . . . . .

Shale, hard, dark gray, papery; low-grade oil shale.

Sandstone, buff, medium grained; numerous partings of hard sandy shale.

Sandstone, buff, very thin bedded

Shale, dark gray, papery; trace of oil

Shale, sandy, interbedded with irregular thin sandstones

Shale, hard, sandy, interbedded with hard light-gray shale that shows trace of oil.

Shale, sandy, and thin sandstone........

Shale, bluish gray, hard, flaky; shows trace of oil .

Shale, sandy, and thin sandstones.......

Clay shale, sandy ........................

Sandstone, brown, medium grained, irregularly bedded........................

Shale, gray-green, hard; trace of oil; few thin lenses of very fine sand.......

Sandstone, brown, soft, fine grained, mas-

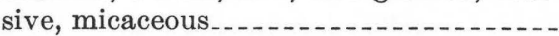

Shale, bluish gray, sandy ..............

Sandstone, buff, soft, medium to coarse grained, massive, micaceous...........

Shale, gray, hard, sandy; few thin sandstone lenses; carries a few plant fragments.

Sandstone, drab, soft, medium grained, mi-

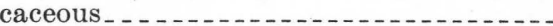

Shale, dark gray, sandy, fissile
Ft. in.

Sandstone, coarse grained, thin bedded... Shale, sandy, interbedded with thin sandstones; both carry abundant mica flakes..

Sandstone, white, very friable, coarse grained . - - -

Shale, dark gray, fissile

Shale, dark brown, papery, tough; low-grade

oil shale.............................

Shale, sandy, and thin sandstones

Sandstone, white, friable, medium grained, micaceous............................

Shale, dark chocolate-brown, soft.........

Shale, sandy, and thin soft sandstones. . - -

3 Sandstone, white, very soft and sugary, medium grained, micaceous

6 ne, dark reddish brown, hard, coarse grained, cross-bedded . . . . . . . . . . . . .

Sandstone, buff, massive, fine grained....

Sandstone, dark brown, much cross-bedded, medium grained

Clay shale, light brown

Sandstone, buff, soft, coarse grained . . ...

Shale, sandy ........................

Sandstone, brown, irregularly bedded, fine

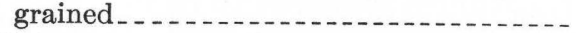

Shale, gray, soft, flaky . . . . . . . . . .

Shale, very dark brown, hard, tough (sample IV-53; 7.5 gallons) ...............

Shale, gray to brownish, flaky

Shale, dark chocolate-brown, papery; lowgrade oil shale

Shale, dark brown to nearly black, papery;

5 low-grade oil shale.-.

Limestone, hard, shaly .................

23 Shale, dark chocolate-brown, papery, somewhat carbonaceous; low-grade oil shale. .

2

1

Clay shale............................

6 Concealed, apparently sandy shale.......

Sandstone, fine grained, thin bedded......

Clay shale, light gray .............

Limestone, hard, shaly ..................

8 Shale, chocolate-brown, papery, tough; lowgrade oil shale...................

Shale, greenish gray, sandy, flaky ........

Shale, dark brown, papery, flexible laminae;

6 low-grade oil shale_............... Shale, sandy, flaky . . . . .

2

2

6 Shale, dark brown, papery; low-grade oil

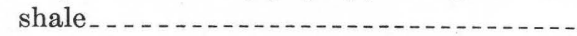
Clay shale, sandy, and thin sandstones....

Shale, nearly black, papery; low-grade oil shale

Silicified bed of small Goniobasis shells

Sandstone, gray, medium grained, thin bed-

16 ded; carries a few larger Goniobasis shells

10 Wasatch formation, main body.
Ft. in.

2

8

5

6

96

2

66

14

66

8

6

2

3 
Sections of Laney shale member of Green River formation in Moffat County, Colo., and Sweetwater County, Wyo.

Locality 4, secs. 22 and 27 , T. 10 N., R. 100 W.

Sandstone, limestone, and clay shale of Bridger formation.

Sandstone, greenish brown, medium to coarse grained, micaceous, cross-bedded _ -

Clay shale, sandy

Sandstone, greenish brown, medium grained, cross-bedded

Sandstone, greenish brown, medium grained,

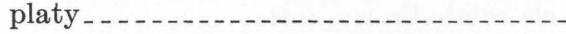

Clay shale, sandy

Shell marl, largely Goniobasis shells

Clay shale, greenish gray ................

Sandstone, dark brown, medium grained, crudely bedded

Clay shale, gray

Candstone, brown, mediu

Clay shale, greenish gray, hard..........

Sandstone, brown, platy

Clay shale, gray

Sandstone, hard, limy, medium grained; carries Goniobasis shells

Clay shale, sandy

Sandstone, dark brown, platy

Alga reef, calcareous; some calcareous shale _..............................

Clay shale, gray

Sandstone, gray, fine grained

Clay shale, greenish gray

Sandstone, brown, shaly

Limestone, shaly, buff

Shale, brown, flaky

Shale, hard, limy

Shale, buff, blocky

Sandstone, light gray, sugary textured, medium grained, friable, massive . . . . . -

Clay shale, sandy, pale green ..........

Sandstone, greenish gray, fine grained....-

Clay shale, greenish gray

Sandstone, gray, medium grained........

Clay shale, greenish gray _............

Shale, calcareous, platy _............

Clay shale, gray

Shale, calcareous, platy ...............

Clay shale, gray

Shale, calcareous, hard, platy ...........

Clay shale, gray; contains lenses of loose fine to coarse sand

Limestone, buff, shaly, hard, blocky . .....

Shale, yellowish brown, lumpy ...........

Limestone, brown, hard, impure, in part crystalline

Shale, gray to brown, platy and flaky .....

Sandstone, light gray, friable, medium to coarse grained ..........................

Clay shale, greenish gray, lumpy and flaky

Limestone, shaly, buff, hard, blocky .....

Clay shale; contains water-rounded clay balls .

Shale, buff, hard, platy

2

2
Clay shale, light gray; contains waterrounded clay balls ................... Marl, shaly; irregular bedding; carries pelecypod shells _....................

Alga reef, calcareous, in part silicified; carries some oolites

6 Clay shale, greenish gray, lumpy ........ Sandstone, very friable, very fine grained.Shale, carbonaceous; partly humified plant remains abundant

Shale, gray, flaky and lumpy

Shale, very carbonaceous

Clay shale, gray

Sandstone, massive, medium grained......

6 Sandstone, extremely friable, very fine grained............................

Sandstone, medium grained...........

Concealed, probably clay shale

Limestone, shaly, hard, buff

3 Concealed, probably soft sandstone and clay shale

Shale, buff, hard, platy; trace of oil_...... Shale, brown, hard, limy

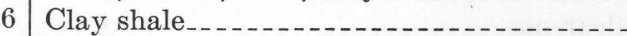

Clay shale, sandy

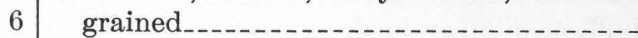

Sandstone, brown, very friable, medium

Clay shale, greenish gray ................

Sandstone, gray, fine grained, banded.....

Shale, brown, carbonaceous; thin shell

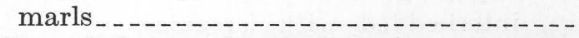

Clay shale, sandy; lenses of soft sandstone

Clay shale, gray-green

Shale, brown to black, carbonaceous .....-

Concealed, probably clay shale..........

Shiny black, soft, earthy matter; yields some oil_......................

Concealed, probably clay shale..........

Clay shale, gray-green, sandy _.........

Clay shale, gray

Shale, papery; poorly exposed...........

Shale, dark chocolate-brown, hard, tough (sample 0114-A; 10 gallons) ...........

Shell marl, containing flat gastropods, fish vertebrae, and bone fragments

Ft. in.

Shale, limy, brown; carries plant fragments;

low-grade oil shale_...................

Shale, limy, hard.

Shale, chocolate-brown, hard, tough; lowgrade oil shale.

Clay shale, gray

11 Shale, reddish brown, carbonaceous, very fissile; numerous plant fragments......

Sandstone, friable, very fine-grained car-

1.4 bonaceous partings . . 4 . Clay shale, gray

10 Shale, brown, platy .................

17 Shell marl; Goniobasis and Unio shells....

6


Shale, platy; carries ostracodes

Shell marl; Goniobasis shells.

Shale, dark gray; interbedded thin shell marls............. Limestone, shaly, hard

Shale, dark-brown, hard; carries ostracodes; low-grade oil shale...............

Shell marl, limy; largely ostracodes...-.--

Shale, dark brown, hard, platy ...........

Shell marl, sandy; mostly small pelecypods_

Shale, gray-brown; plant fragments.......

Clay shale, dark greenish gray, waxy .....

Shale, gray-brown, soft, fissile; carries ostracodes and fragments of fish teeth.-

Shale, dark brown, papery _.............

Limestone, blue-gray, hard, lenticular....-

Shale, hard, pale green, blocky (sample 086-A; 4 gallons) ..................

Limestone, gray, hard.................

Shale, brown, hard, locally papery; lowgrade oil shale..................

Limestone, buff, shaly, hard ............

Shale, brown, hard, platy; some beds are low-grade oil shale....................

Sandstone, limy; carries Goniobasis shells

Shale, brown, soft, platy _............

Shale, dark brown, carbonaceous ........

Sandstone, limy, hard

Shale, dark brown, hard, platy; low-grade oil shale

Sandstone, platy ........................

Shale, greenish brown, soft

Limestone, sandy; carries ostracodes......

Shale, brown, soft ...................

Shale, yellowish brown; abundant plant

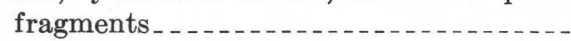

Shale, limy, soft, laminated............

Shale, light brown, laminated; low-grade oil shale

Shale, gray, flaky

Shale, limy, yellow-brown, papery, soft....

Shale, light gray, hard, platy ...........

Limestone, sandy, crystalline...........

Shale, light brown, soft . . . . .............

Shale, limy, yellowish gray, soft; traces of oil__._. _.

Limestone, shaly, hard................

Shale, gray, flaky

Sandstone, yellow, coarse grained

Shale, limy, yellow-brown, platy .........

Limestone, sandy, lenticular

Clay shale, gray ......................

Shale, limy, light brown, papery, soft....-

Limestone, buff, shaly, hard _............

Shale, limy, light yellowish brown, papery --

Clay shale, reddish gray . . . . . . . . . . . . . .

Alga reef, calcareous; abundant ostracodes_

Limestone, oolitic, hard

Shale, limy, yellow brown

Limestone, gray, hard

Clay shale.
Ft. in.

11 Limestone, buff, shaly, hard.

1 Clay shale, light brown ............... Shale, limy, papery, light brown, soft_....

29

6 Sandstone, medium grained. Shale, light brown, laminated; trace of oil_

4 Sandstone, medium grained

6 Limestone, gray, hard

Shale, limy, papery

110 Sandstone, buff, limy, medium to coarse Clay shale, gray $\ldots \ldots$

Shale, limy; faint bedding ............

4 Shale, dark gray, papery; trace of oil .....-

5 Sandstone, buff, medium to coarse grained; carries few small pebbles; locally crossbedded.

4 Sandstone, shaly, blocky _.............. Sandstone, buff, soft, friable, coarse grained Sandstone, limy, buff, fine grained....... -

5 Shale, greenish, limy Shale, limy, light yellow-brown, laminated Shale, limy, hard, not laminated ........

3 Shale, limy, light yellow, papery ......... mestone, shaly, lenticular Shale, sandy and limy; plant fragments...

Clay shale, gray ....................... Shale, light brown, papery

3 Clay shale, dark gray _.................

10 Sandstone, buff, fine grained............ Clay shale, gray; grades up into gray

1 papery shale.

Clay shale of Cathedral Bluffs tongue of Wasatch formation.

Top of bluff.

Sandstone; carries Goniobasis and Unio shells.

Shale and thin sandstones..............

Sandstone, coarse grained...........

Shale and thin sandstones..............

Shale, limy, buff; trace of oil ............

Shale, carbonaceous and clayey ..........

4 Sandstone, fine grained, thin bedded......

21 Shale, carbonaceous and clayey ........

Ft. in.

12 10

96

2

9

$12 \quad 10$

4

8

Shale, limy, hard....................

8 Shale, gray, carbonaceous and clayey ..... Shale, greenish; plant fragments......... Limestone, shaly, gray _.............

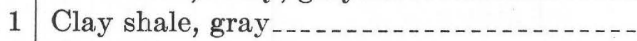

9 Shale, limy, hard $\ldots \ldots$ Shale, light brown, platy; low-grade oil shale.

Ft. in.

$11 \quad 10$

2

$28 \quad 6$

5

6

3

218

23

416

14

1
2

3

Clay shale, sandy; contains thin beds of

3 Sandstone, brown, coarse grained......

2 Shale, limy, soft.......................

3 Shale, brown; some plant fragments. . . . . 
Clay shale, gray and pink $\ldots \ldots \ldots$ Sandstone, gray, hard, platy, thin bedded . Shale, limy, buff, platy Shale, limy, buff, hard; trace of oil ....... Shale, gray; lower 48 feet limy; upper part low-grade oil shale

Shale, brown to black, carbonaceous. Shale, sandy, gray Sandstone, fine to medium grained . . . . . . Shale, sandy, hard.

Shale, limy, hard, buff . . . . . . . . . . .

Sandstone, gray, fine grained_..........

Shale, sandy, fissile.

Shale, carbonaceous

Shale, limy

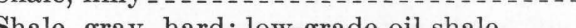

Shale, gray, soft; trace of oil

Shale, brown, hard; low-grade oil shale...-

Shale, limy, hard, barren.............

Shale, brown, laminated; low-grade oil shale.

Shale, very limy, brown; low-grade oil shale

Shale, limy, hard, barren

Shale, brown, laminated, hard.

Shale, limy, hard (not sampled)

Shale, brown, laminated, hard sample IIgallons) $86-88 ; 9.5$

Shale, limy, hard, barren

Shale, gray to brown, hard, laminated; lowgrade oil shale

Limestone, shaly, buff, hard . . .........

Shale, gray to brown, hard, laminated; lowgrade oil shale

Limestone, shaly, buff, hard............

Shale, brown; weathers papery; low-grade oil shale

Shale, black, carbonaceous

Shell marl, silicified

Sandstone, gray, hard, fine grained

Shate, platy, silicified

Shale, brown, fissile; low-grade oil shale...

Shale, silicified.

Shale, gray, fissile.

Shale, limy, hard

Shale, dark brown, hard, tough; low-grade oil shale

Shale, silicified

Shale, gray to brown; low-grade oil shale..-

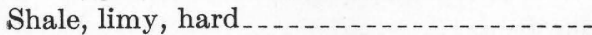

Shale, dark brown, hard, platy; low-grade oil shale

Limestone, silicified Shale, brown to buff; trace of oil . . . . . . .

Clay shale, greenish $\ldots \ldots$

Shale, gray, soft

Shale, dark gray, hard; low-grade oil shale

Shale, gray, hard, blocky; trace of oil; interbedded with few thin hard shaly limestones

Shale, gray, papery; limy shale interbedded. Clay shale, greenish, waxy -........Shale, limy, yellow, hard.

Shale, light brown, laminated.

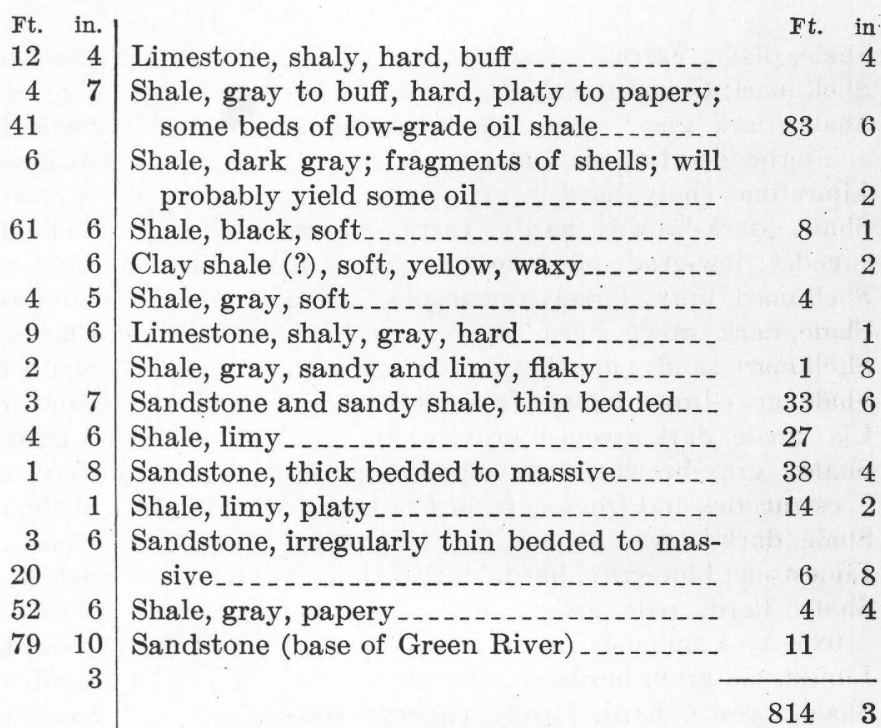

Locality 6, sec. 3, T. 13 N., R. 99 W.

Top of bluff.

[According to Schultz.27]

Sandstone, coarse grained, not massive...Sandstone, containing fossil shells ........ Sandstone, coarse grained, thin bedded...Covered, probably sandy shale Sandstone, coarse Covered, mostly shale.............. Shale, papery, drab, lean .............. Shale, thin, barren, and sandstone......Shale, drab, thin, lean_................ Shale, thin, drab, barren Shale, thin, lean Sandstone, concretionary ............. Shale, thin, lean Oolite and chert.

Shale, thin bedded, lean_.......... 14

Shale, thin bedded; weathers blue; rich.

Shale, gray, sandy (not included in sample)

Sandstone, yellow (not in- 30 galcluded in sample)

lons.)

Shale, thin bedded; weathers
25
Shale, yellow, sandy

Shale, papery, lean_............ 40

Shale, drab, fissile............. 10

10 Sandstone, concretionary ........ 1

5 Shale, drab, papery (over 15 gallons) _...- 13

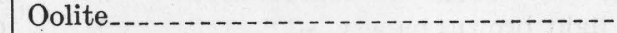

2 Shale, drab, papery (over 15 gallons) -....-

Sandstone, oolitic

Shale, drab, fissile.......

Sandstone, micaceous _.............

Sandstone, yellowish

1

${ }^{27}$ Schultz, A. R., Oil possibilities in and around Baxter Basin, in the Rock Springs uplift, Sweetwater County, Wyo.: U. S. Geol. Survey Bull. 702, p. 54, 1920. 
Shale, drab, papery, barren Sandstone, shaly, yellowish

Shale, greenish drab

Cathedral Bluffs tongue of Wasatch formation.

Locality 7, secs. 17 and 19, T. 17 N., R. 106 W. [According to Winchester. ${ }^{28}$ ]

Sandstone, massive, brown, coarse ("Tower sandstone" of Powell)

Sandstone, thin bedded . . . . . . . . . . .

Shale, papery, gray

Sandstone, shaly, gray

Shale, sandy, lean.......................

Shale, hard; contains fish remains (sample $120 ; 14$ gallons) .....................

Shale, lean.

Shale, thin, with lenses of very rich waxy shale

Shale, hard

Shale, hard (sample 119; 12 gallons) $\ldots . .$.

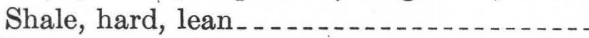

Shale, gray, sandy

Shale, hard, rich (more than 15 gallons) ...

Shale, gray, sandy, thin sandstones, and a few 1 to 3 inch beds of rich shale......

Shale, hard, thin, medium rich...........

Shale, barren.

Shale, medium, with large gypsum crystals

Shale, thin, barren

Shale, medium, with gypsum crystals . .....

Shale, gray, sandy

Shale, medium, with gypsum crystals....

Shale, hard, rich (over 15 gallons) ........

Sandstone, thin, gray

Shale, hard, rich (over 15 gallons) ........

Shale, gray, sandy .......................

Shale, hard, rich (over 15 gallons) ......

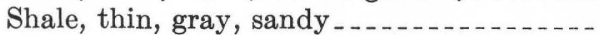

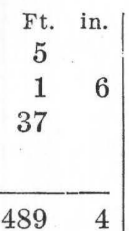
Ft. in

125 35

25

32

65

5

20

55

15

5

12

20

1

1

15

1

80

26

26
1

16

8

17

$9 \quad 2$

${ }^{28}$ Winchester, D. E., Oil shale of the Rocky Mountain region: U. S. Geol. Survey Bull. 729, pp. 124, 125, 1923.
Shale, hard, rich (over 15 gallons) . . . .

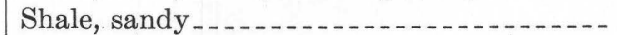

Sandstone, gray .........

Shale, sandy, greenish ....................

Sandstone, gray, thin bedded........

Shale, sandy, green

Shale, sandy, thin bedded, gray .........

Sandstone and shale, green, in beds 2 feet

thick; sandstone concretionary -......-

Shale, sandy, gray, slope............

Sandstone, massive, cross-bedded, forming

ledge and capping hill_..........

Shale, forming slope...................

Sandstone, rather massive, forming ledge.- -

Shale, soft, thin, platy, barren . ........

Shale, medium hard, rather thin, very lean

Shale, medium hard (sample 116; 4 gallons) -

Shale, sandy, lean to barren............

Shale, medium hard, very lean.........

Shale, lean

Sandstone, brown, persistent

Shale, lean

Shale, hard to medium hard (sample 115; 9 gallons)

Shale, lean to barren

Shaly sandstone, barren .............

Shale, sandy, forming slope, lean

Shale, hard (sample 114, lower $4 \frac{1}{2}$ feet; 11 gallons)

Shale, hard

Sandstone.............. (sample 112;

Shale, fairly soft, thin bedded_. 9 gallons) _-

Shale, hard..............

Shale, hard, rich (sample 111; 19 gallons) -

Ft. in.

118

4

6

1

27

21

58

97

5

43

10

30

$\begin{array}{ll}4 & 11\end{array}$

$4 \quad 10$

70

10

46

8

36

46

$75 \pm$

15

47 Shale, soft................) $\quad$ ( 7 Shale, hard, rich_........ (sample 109; $2 \quad 5$ Shale, soft................ 11 gallons) Shale, hard, rich..........

\section{0} ( 